\title{
Mapping Sali Rice Areas of Meghalaya Using Geospatial Technology
}

\author{
Pratibha Thakuria Das*, Priyanka Longmailai, Dharmendra Kumar Jha, \\ Bipul Saikia, Tangwa Lakiang and P.L.N. Raju
}

\begin{abstract}
North Eastern Space Applications Centre, Department of Space, Govt. of India, Umiam, Meghalaya-793103, India
\end{abstract}

*Corresponding author

K e y w o r d s
Sali rice, Remote
Sensing, GIS,
Rice ecosystem,
Meghalaya

\section{A B S T R A C T}

Sali rice areas were mapped from multispectral LISS IV images of Resourcesat-2A satellite by using standard visual interpretation technique. The study showed that sali rice was cultivated in 102574.3 ha area which is $4.6 \%$ of the total geographical area of Meghalaya and it is distributed in all 39 blocks of 11 districts of the state. Sali rice cultivation is highest in West Garo Hills district that cover $21.9 \%$ area and lowest in South West Khasi Hills district $(2117.5 \mathrm{ha} / 2.1 \%)$. Selsella block is having the highest sali rice growing areas followed by Betasang and Zikzak block. The lowest area is found in Pynursla block of East Khasi hills district. Based on rice growing ecosystem of Meghalaya, it is found that cultivation of low altitude rice is highest in the state that cover $64.2 \%$ area followed by mid altitude $(20 \%)$ and high altitude rice (15.8\%). It is also observed that the low altitude rice is the highest in West Garo Hills and lowest in the South West Khasi hills district. Mid altitude rice is highest in West Jaintia Hills and Ribhoi district where as high altitude rice is found only in Khasi and Jaintia hills.

\section{Introduction}

Rice is a major food crop of Meghalaya occupying an average annual area of $1,11,178$ ha with total production of 3,01,076 Metric Tons. Rice is grown in the state in a wide range of climatic conditions ranging from deep water to high altitudes. The rice that is grown in the state has been classified into three classes i.e. Boro or Spring/Summer rice, Sali or Kharif rice / winter rice and Ahu or Autumn rice. Out of the total rice grown area, 63862 ha area is under sali rice alone that occupies $57 \%$ of the total rice cropped area producing an annual average of 160722 Metric Tons during the period 2016-17 (www. megagriculture.gov.in). The area under Boro and Ahu rice is 33646 and 13670 
ha respectively. The average yield is the highest in Boro rice ( $4608 \mathrm{~kg} / \mathrm{ha}$ ) followed by Sali $(2524 \mathrm{~kg} / \mathrm{ha})$ and Ahu rice $(2337 \mathrm{~kg} / \mathrm{ha})$. However, food security is uncertain, as current annual rice consumption has exceeded annual rice production. The annual shortfall of food grain is estimated to be of the order of 122 thousand tones (www. megplanning.gov.in). It is therefore evident that the state is not self sufficient in the production of food grain.

The spatio-temporal distribution and dynamics of rice cultivation in a state helps to understand growing food demand, water scarcity, etc. Accurate and on-time information on spatial distribution of rice would be useful for stakeholders (cultivators, fertilizer/pesticide manufacturers and agriculture extension agencies) to effectively plan supply of inputs, market activities. Also, government agencies can plan and formulate policies regarding food security. In addition, the data on rice area would be useful as an input to estimate crop health, water demand and crop yield at field/regional level (Mohite et al., 2018). Since problems with food security persist in the state of Meghalaya are robust, reliable tool for mapping and early forecasting of rice production are thus critical. Therefore reliable and timely estimates of rice crop areas and its production are essential for providing information for planners and decision makers to formulate policies in the case of shortfall or surplus.

The most common and widely used methods for estimating rice cultivated areas are the use of agricultural statistical data acquired through field visits and interviewing the farmers. The methodology for mapping area under rice cultivation is basically done through annual/seasonal sample surveys based on a number of sample clusters that are constituted all over the country for measuring cultivated area during the crop growing season. Each cluster is visited many times and areas are recorded by the field staffs, checked, and then processed by regional statistical officers. Despite its invaluable ability for understanding historical trends in rice area, this method is extremely tedious, timeconsuming, less precise, costly, inconsistent and labour-intensive (Prasad et al., 2006; Bala and Islam, 2008). Therefore scientific modern technology to be adopted for estimating rice cultivated areas.

In this context, remote sensing-based methods have already been proven as an effective alternative for mapping rice area (Singh et al., 2014; Nema et al., 2018; Rehman et al., 2009). The benefits of remote sensing technology include: (i) spatial coverage over a large geographic area; (ii) availability during all seasons; (iii) relatively low cost; (iv) efficient analysis; (v) they provide information in a timely manner; and (vi) they are capable of delineating detailed spatial distributions of areas under rice cultivation. The user requires fast, reliable (accurate), less costly and least labour-intensive ways which can be achieved through remote sensingbased method. Rice area mapping at field, district, regional and national scale has been carried out in the past using various approaches which involves use of single date or time series optical as well as microwave/Synthetic Aperture RADAR (SAR) data (Yin et al., 2019; Qin et al., 2015; Nguyen et al., 2015; Neetu et al., 2014; Karydas et al., 2015; Ok et al., 2015,; Mostafa et al., 2015).

Meghalaya Rice Mission is a programme to increase rice production and productivity in the state to meet the consumption requirement and to bridge the deficit between demand and availability to consumers. Directorate of Agriculture, Govt. of Meghalaya has taken up action on the recommendations of the State Consultant, State Rice Mission, Dr. Sushil 
Pandey, ex Rice Economist from IRRI, Manila, Philippines. One of his recommendations suggests that under Mini Mission 1, GIS and RS technology to be utilised for identification, mapping of rice areas and suitability analysis for extending the boro paddy areas in the State. One action already has been taken up by Directorate of Agriculture, Govt. of Meghalaya on identification of areas suitable for expansion of Boro rice cultivation in the state which was executed by North Eastern Space Applications Centre (NESAC) and the project is being implemented by the user department. In continuation to the above, Directorate has proposed to create scientific database on Sali rice areas (Winter Rice) for planning, targeting and increasing production and productivity of rice in order to promote food security goals of the State. Based on the requirement of Directorate of Agriculture, Govt. of Meghalaya, NESAC has taken up the present study on Identification and mapping of Block wise sali paddy (winter rice) areas in Meghalaya using remotely sensed data, GIS techniques and ground based observations.

\section{Materials and Methods}

Resourcesat-2A Ortho rectified LISS IV (multispectral) images of 2017-18 were used to derive information on the spatial distribution of sali rice areas in Meghalaya. The methodology adopted consists of satellite data preparation, interpretation (on-screen visual), ground truth data collection, map finalization, quality checking of final maps and databases. The sali paddy areas as seen in the satellite data are delineated on screen using standard visual interpretation technique and prepared preliminary interpretation map. The preliminary interpreted map was used for collection of ground truth (GT) data from 350 locations covering the entire state. The map was finalised by using the GT data, high resolution alternate foreign satellite images like Komsat and Google earth images and incorporating field knowledge of block and district agriculture officers of the state. The existing village location map was updated by using Google earth images and Soil Health Card data. Villages nearby large patches of sali paddy areas were identified and listed block wise.

In Meghalaya three rice ecosystems are available i.e. low altitude rice upto $800 \mathrm{~m}$, mid altitude $800-1300 \mathrm{~m}$, high altitude rice above $1300 \mathrm{~m} \quad$ (Source: http//www. megagriculture.gov.in). The elevation map was derived from Digital Elevation Model (DEM) prepared from Cartosat satellite images. The elevation map was classified into three classes viz. $<800 \mathrm{~m}, 8000-1300 \mathrm{~m}$ and $>1300 \mathrm{~m}$. The elevation map was overlaid with sali rice map in GIS environment and analysed the data by using analysis tool of ArcGIS software. The sali rice areas were stratified into three rice ecosystem as per package of practices of rice for Meghalaya.

\section{Results and Discussion}

From the study it is observed that sali rice is grown in 102574.3 ha which is $4.6 \%$ of the total geographical area of Meghalaya during 2017-18. It is observed that sali rice is cultivated in all 39 blocks of 11 districts of the state (Figure 1). The study shows that sali rice cultivation is highest in West Garo Hills district which cover $21.9 \%$ of the total sali rice growing areas where as the lowest area i.e 2117.5 ha $(2.1 \%)$ is found in South West Khasi Hills district (Table 1). From the study it is found that Selsella block of West Garo Hills district is having the highest sali rice growing areas followed by Betasang and Zikzak block (Table 2). 
Table.1 District wise area under sali rice

\begin{tabular}{|l|c|c|}
\hline District & $\begin{array}{c}\text { Area } \\
\text { (ha) }\end{array}$ & $\begin{array}{c}\% \\
\text { area }\end{array}$ \\
\hline $\begin{array}{l}\text { South West Khasi } \\
\text { Hills }\end{array}$ & 2117.5 & 2.1 \\
\hline East Jaintia Hills & 3593.0 & 3.5 \\
\hline South Garo Hills & 4827.7 & 4.7 \\
\hline East Garo Hills & 4943.4 & 4.8 \\
\hline East Khasi Hills & 8087.7 & 7.9 \\
\hline North Garo Hills & 8367.1 & 8.2 \\
\hline RiBhoi & 9544.7 & 9.3 \\
\hline West Jaintia Hills & 10869.4 & 10.6 \\
\hline West Khasi Hills & 13569.2 & 13.2 \\
\hline $\begin{array}{l}\text { South West Garo } \\
\text { Hills }\end{array}$ & 14222.7 & 13.9 \\
\hline West Garo Hills & 22431.9 & 21.9 \\
\hline Total & 102574.3 & 100.0 \\
\hline
\end{tabular}

Table.2 Block wise area under sali rice in Meghalaya

\begin{tabular}{|c|c|c|c|c|c|c|c|}
\hline District & Block & Area(ha) & Area(\%) & District & Block & Area (ha) & Area (\%) \\
\hline \multirow{3}{*}{$\begin{array}{l}\text { East } \\
\text { Garo } \\
\text { Hills }\end{array}$} & Rongjeng & 3278.5 & 3.1 & \multirow{2}{*}{$\begin{array}{c}\text { South Garo } \\
\text { Hills }\end{array}$} & Gasuapara & 2138.0 & 2.0 \\
\hline & Samanda & 611.1 & 0.6 & & Rongara & 689.2 & 0.6 \\
\hline & Songsak & 1110.8 & 1.0 & \multirow{2}{*}{$\begin{array}{l}\text { South West } \\
\text { Garo Hills }\end{array}$} & Betasing & 8227.6 & 7.7 \\
\hline \multirow{2}{*}{$\begin{array}{l}\text { East } \\
\text { Jaintia }\end{array}$} & Khliehriat & 2019.3 & 1.9 & & Zikzak & 6774.4 & 6.4 \\
\hline & Saipung & 1607.4 & 1.5 & \multirow{2}{*}{$\begin{array}{l}\text { South West } \\
\text { Khasi Hills }\end{array}$} & Mawkyrwat & 1712.8 & 1.6 \\
\hline \multirow{8}{*}{$\begin{array}{l}\text { East } \\
\text { Khasi } \\
\text { Hills }\end{array}$} & Mawkdok & 776.9 & 0.7 & & Ranikor & 515.5 & 0.5 \\
\hline & Mawkynrew & 862.4 & 0.8 & \multirow{6}{*}{$\begin{array}{c}\text { West Garo } \\
\text { Hills }\end{array}$} & Dadenggre & 2030.2 & 1.9 \\
\hline & Mawphlang & 1566.8 & 1.5 & & Dalu & 2934.3 & 2.8 \\
\hline & Mawryngknen & 818.2 & 0.8 & & Gambegre & 501.4 & 0.5 \\
\hline & Mawsynram & 3350.6 & 3.2 & & Rongram & 950.6 & 0.9 \\
\hline & Mylliem & 565.1 & 0.5 & & Selsella & 11511.5 & 10.8 \\
\hline & Pynursla & 63.5 & 0.1 & & Tikrikilla & 5131.0 & 4.8 \\
\hline & Shella & 604.3 & 0.6 & \multirow{3}{*}{$\begin{array}{l}\text { West } \\
\text { Jaintia } \\
\text { Hills }\end{array}$} & Amlarem & 945.0 & 0.9 \\
\hline \multirow{2}{*}{$\begin{array}{l}\text { North } \\
\text { Garo }\end{array}$} & Kharkutta & 1748.6 & 1.6 & & Laskien & 3379.8 & 3.2 \\
\hline & Resubelpara & 6679.5 & 6.3 & & Thadlaskien & 6688.3 & 6.3 \\
\hline \multirow[t]{3}{*}{ RiBhoi } & Jirang & 972.9 & 0.9 & \multirow{4}{*}{$\begin{array}{c}\text { West Khasi } \\
\text { Hills }\end{array}$} & Mairang & 4141.5 & 3.9 \\
\hline & Umling & 3072.9 & 2.9 & & Mawshynrut & 2252.7 & 2.1 \\
\hline & Umsning & 5828.7 & 5.5 & & Mawthadrais & 4505.1 & 4.2 \\
\hline \multirow{3}{*}{$\begin{array}{l}\text { South } \\
\text { Garo }\end{array}$} & Baghmara & 1018.0 & 1.0 & & Nongstoin & 3267.3 & 3.1 \\
\hline & Chokpot & 1383.9 & 1.3 & & & & \\
\hline & & & & & Total & 102574.3 & 100.0 \\
\hline
\end{tabular}


Table.3 Grouping of rice fields based on its size (ha)

\begin{tabular}{|c|l|l|r|r|}
\hline Sl. No. & Field size (ha) & Class name & Area (ha) & Field numbers \\
\hline $\mathbf{1}$ & $0.01-0.05$ & Very marginal & 5.1 & 264 \\
\hline $\mathbf{2}$ & $0.05-1$ & Marginal & 10457.7 & 23545 \\
\hline $\mathbf{3}$ & $1-2$ & Small & 9316.8 & 6570 \\
\hline $\mathbf{4}$ & $2-4$ & Semi medium & 10830.1 & 3945 \\
\hline $\mathbf{5}$ & $4-10$ & Medium & 15536.7 & 2638 \\
\hline $\mathbf{6}$ & $10-100$ & Large & 37229.0 & 1563 \\
\hline $\mathbf{7}$ & $100-943$ & Very large & 19199.5 & 94 \\
\hline & Total & & 102574.3 & 38619 \\
\hline
\end{tabular}

Table.4 District wise area under different rice ecosystem

\begin{tabular}{|l|l|r|r|r|}
\hline Districts & $\begin{array}{l}\text { Low altitude } \\
\mathbf{( 0 - 8 0 0 m )}\end{array}$ & $\begin{array}{r}\text { Mid altitude } \\
\mathbf{( 8 0 0 - 1 3 0 0 m )}\end{array}$ & $\begin{array}{c}\text { High altitude } \\
(\mathbf{8 1 3 0 0 m})\end{array}$ & Total \\
\hline East Garo Hills & 4894.2 & 49.2 & - & 4943.4 \\
\hline East Jaintia Hills & 547.8 & 2964.6 & 74.5 & 3586.9 \\
\hline East Khasi Hills & 1796.7 & 1335.8 & 4955.2 & 8087.7 \\
\hline North Garo Hills & 8367.1 & - & - & 8367.1 \\
\hline RiBhoi & 5788.6 & 3756.2 & - & 9544.8 \\
\hline South Garo Hills & 4827.7 & - & - & 4827.7 \\
\hline South West Garo Hills & 14222.7 & - & - & 14222.7 \\
\hline South West Khasi Hills & 515.5 & 15.3 & 1586.7 & 2117.5 \\
\hline West Garo Hills & 22411.4 & 20.5 & - & 22431.9 \\
\hline West Jaintia Hills & 541.4 & 8820.2 & 1508.0 & 10869.6 \\
\hline West Khasi Hills & 1938.6 & 3537.9 & 8092.8 & 13569.4 \\
\hline Total & 65857.2 & 20500.4 & 16217.1 & 102574.3 \\
\hline \% area & 64.2 & 20.0 & 15.8 & 100.0 \\
\hline
\end{tabular}

Figure.1 Spatial distribution of sali rice in Meghalaya

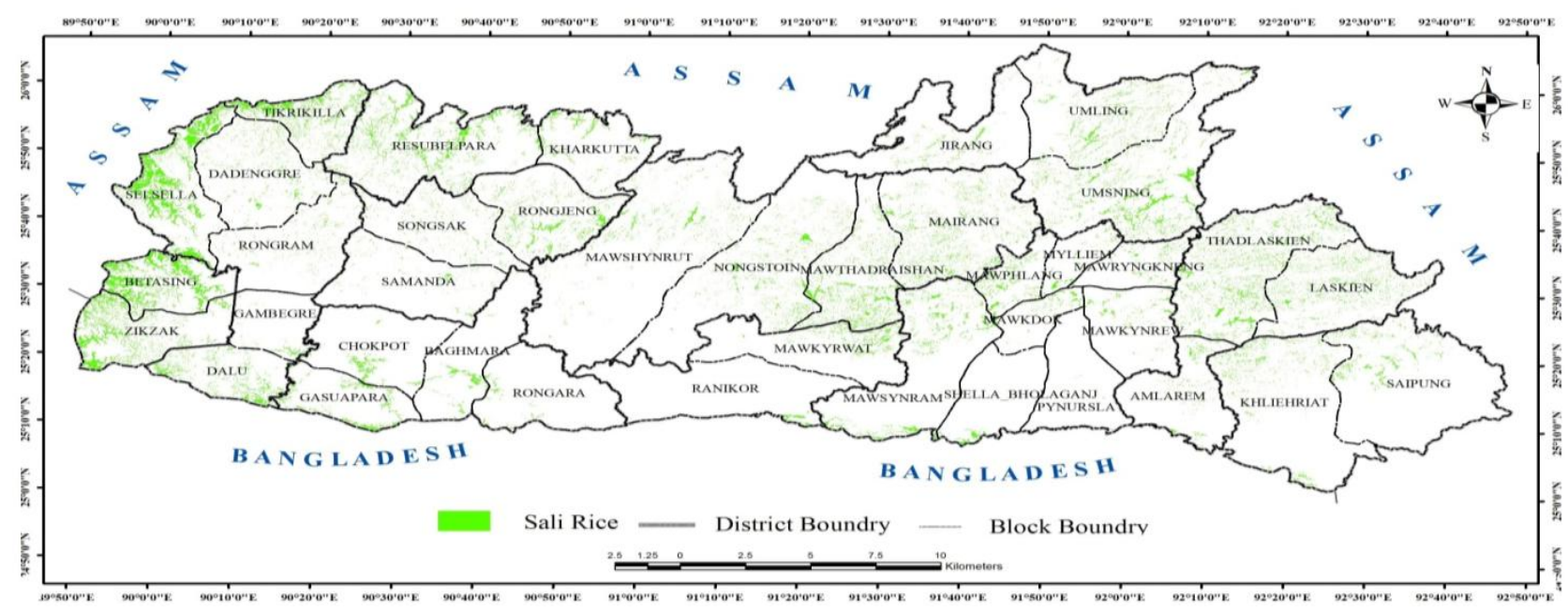


Figure.2 Rice ecosystem of Meghalaya

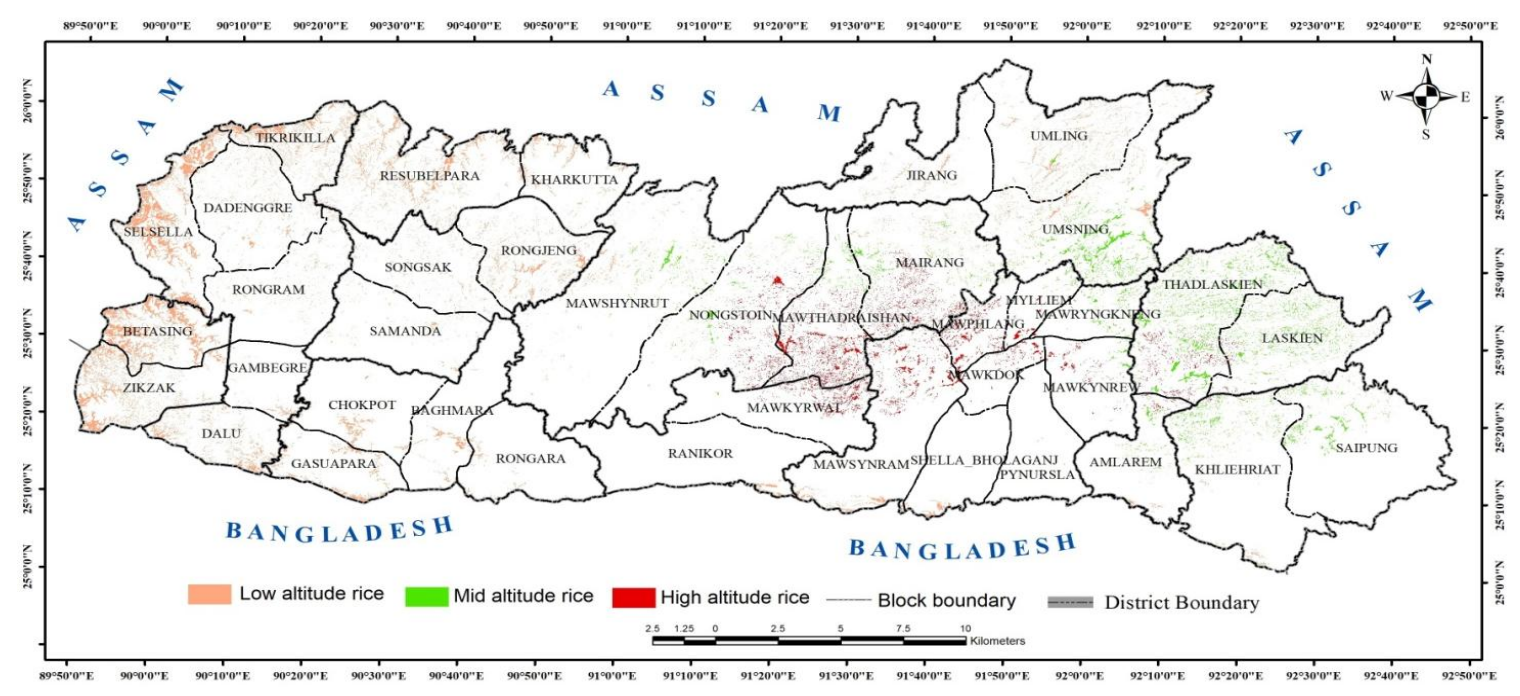

Based on size of each polygon representing rice fields, the polygons were classified into 7 groups viz. 0.01-0.05 ha, 0.05-1ha, 1-2 ha, 24 ha, 4-10 ha, 10-100 ha and >100ha. It is observed that maximum rice fields are in the class of 10-100 hectares. It is also observed that even though number of polygon is highest in the class of 0.05-1 ha (23545) and $1-2$ ha (6570) but total area is less compared to other class (Table 3 ). It is found that rice fields with >10ha area is found highest in West Garo hills district and rice fields size between 2-10ha are found highest in West Khasi hills followed by West Garo and West Jaintia hills districts. Marginal to small fields are found highest in West Khasi hills and West Jaintia hills districts. The rice fields which size are less than 10ha was used for finding out the list of villages which are falling within one kilometer distance. Block wise map showing villages within one kilometer distance of rice fields are prepared and name of villages are listed in tables and submitted to the user department. These maps are being used by the user department for implementing different schemes to increase rice production in the state.
The rice ecosystem map was derived by overlaying rice map with elevation map classified into three classes viz. $<800 \mathrm{~m}, 8000$ $1300 \mathrm{~m}$ and $>1300 \mathrm{~m}$ in GIS environment. From the study it is found that cultivation of low altitude rice is highest in the state (Table 4) that cover $64.2 \%$ area followed by mid altitude $(20 \%)$ and high altitude rice (15.8\%). It is also observed that the low altitude rice is the highest in West Garo Hills district and lowest in the South West Khasi hills district. Mid altitude rice is highest in West Jaintia Hills and Ribhoi district where as high altitude rice is found only in Khasi and Jaintia hills districts i.e. East khasi hills, West khasi hills, South west khasi hills, East Jaintia and West Jaintia hills districts (Figure 2).

From accuracy assessment it is found that the accuracy of the mapping is $90 \%$. The $10 \%$ error in the mapping is due to misclassification of the vegetable growing areas and rice fallow land as sali rice. From the field visit, it is found that the vegetable growing areas and rice fallow lands adjacent to sali rice fields situated in the same physiographic condition and field size are smaller than 0.01 ha has contributed to 
mapping error. It is also found that misclassification of vegetable growing areas as sali rice is highest in the East Khasi hills district especially in the Mylliem block. During the sali rice growing season, rice fallow lands are mostly covered with grass and it become difficult to differentiate rice and grass in the satellite image because both are looking similar.

\section{Acknowledgements}

The authors would like to thank Directorate of Agriculture, Govt. of Meghalaya for funding of the project and also for providing necessary support during ground truth data collection. The authors also would like to thank district agriculture officers of 11 districts for extending support during field visit and in implementing the project in their respective district.

\section{References}

Bala S.K. and Islam A.K.M.S. 2008. Estimation of Potato Yield in and around Munshiganj Using Remote Sensing NDVI Data. Institute of Water and Flood Management; Dhaka, Bangladesh. pp. 79.

Karydas, C., Toukiloglou, P., Minakou, C. and Gitas, I. 2015. Development of a rule-based algorithm for rice cultivation mapping using landsat 8 time series. Third International Conference on Remote Sensing and Geoinformation of the Environment (RSCy2015), Proc. of SPIE.

Mohite, Jayantrao; Sawant, Suryakant; Kumar, A.; Prajapati, M.; Pusapati, S.; Singh, D. and Pappula, S. 2018. Operational near real time rice area mapping using multi-temporal sentinel1 SAR observations. ISPRS International Archives of the Photogrammetry, Remote Sensing and
Spatial Information Sciences. XLII-4. 433-438. https://doi.org/10.5194/isprsarchives-XLII-4-433-2018.

Mosleh, Mostafa and Hassan, Quazi \& Chowdhury, Ehsan. 2015. Application of Remote Sensors in Mapping Rice Area and Forecasting Its Production: A Review. Sensors (Basel, Switzerland). 15. 769-791. https://doi.org/10.3390/ s150100769.

Neetu, Prashnani, M., Singh, D. K., Joshi, R. and Ray, S. S. 2014. Understanding crop growing pattern in barddhaman district of west bengal using multi-date risat $1 \mathrm{mrs}$ data. The International Archives of the Photogrammetry, Remote Sensing and Spatial Information Sciences. ISPRS Technical Commission VIII Symposium.

Neetu, Prashnani, M., Singh, D. K., Joshi, R. and Ray, S. S. 2014. Understanding crop growing pattern in barddhaman district of west bengal using multi-date risat $1 \mathrm{mrs}$ data. The International Archives of the Photogrammetry, Remote Sensing and Spatial Information Sciences. ISPRS Technical Commission VIII Symposium.

Nema, S., M.K. Awasthi and Nema, R.K. 2018. Spatial Crop Mapping and Accuracy Assessment Using Remote Sensing and GIS in Tawa Command. Int.J.Curr.Microbiol.App.Sci. 7(5): 3011-3018. doi: https://doi.org/10. 20546/ ijcmas.2018.705.350

Nguyen, D., Clauss, K., Cao, S., Naeimi, V., Kuenzer, C. and Wagner, W., 2015. Mapping rice seasonality in the mekong delta with multi-year envisat asar wsm data. Remote Sensing 7(12), pp. 1586815893.

Ok, Asli Ozdarici., Ok, Ali Ozgun and Schindler, Konrad. 2015. Mapping of Agricultural Crops from Single HighResolution Multispectral ImagesData-Driven Smoothing vs. Parcel- 
Based Smoothing. Remote Sensing. 7: 5611-5638; doi:10.3390/rs70505611.

Prasad A.K., Chai L., Singh R.P., Kafatos M. 2006. Crop yield estimation model for Iowa using remote sensing and surface parameters. Int. J. Appl. Earth Obs. Geoinf. 8:26-33.

Qin, Y., Xiao, X., Dong, J., Zhou, Y., Zhu, Z., Zhang, G., Du, G., Jin, C., Kou, W., Wang, J. and Li, X. 2015. Mapping paddy rice planting area in cold temperate climate region through analysis of time series landsat 8 (oli), landsat $7(\mathrm{etm}+)$ and modis imagery. ISPRS Journal of Photogrammetry and Remote Sensing. 105, pp. 220-233.

Rahman A., Roytman L., Krakauer N.Y., Nizamuddin M., Goldberg M. 2009.
Use of vegetation health data for estimation of Ahu rice yield in Bangladesh. Sensors.9: 2968-2 975.

Singh S.K., Srivastava P.K., Gupta M., Thakur J.K., Mukherjee S. 2014. Appraisal of land use/land cover of mangrove forest ecosystem using support vector machine. Environ. Earth Sci. 71:2245-2255.

www. megagriculture.gov.in

WWw. megplanning.gov.in

Yin, Q.; Liu, M.; Cheng, J.; Ke, Y.; Chen, X. 2019. Mapping Paddy Rice Planting Area in Northeastern China Using Spatiotemporal Data Fusion and Phenology-Based Method. Remote Sens. 11, 1699.

\section{How to cite this article:}

Pratibha Thakuria Das, Priyanka Longmailai, Dharmendra Kumar Jha, Bipul Saikia, Tangwa Lakiang and Raju, P.L.N. 2020. Mapping Sali Rice Areas of Meghalaya Using Geospatial Technology. Int.J.Curr.Microbiol.App.Sci. 9(11): 2714-2721. doi: https://doi.org/10.20546/ijcmas.2020.911.329 